\title{
From Science through Art to Literary and Discursive Interpretation: Rethinking Anthropology from Its Classical to Contemporary Trajectory
}

\author{
Saiful Islam ${ }^{1}$ \\ ${ }^{1}$ Department of Sociology and Anthropology, University Brunei Darussalam (UBD), Brunei \\ Correspondence: Saiful Islam, Department of Sociology and Anthropology, University Brunei Darussalam, Jalan \\ Tungku Link, Brunei. Tel: 673-246-3001 Ext.2056. E-mail: saif126@gmail.com
}

Received: May 7, 2013 Accepted: June 22, 2013 Online Published: August 30, 2013

doi:10.5539/ass.v9n11p148

URL: http://dx.doi.org/10.5539/ass.v9n11p148

\begin{abstract}
The emergence of anthropology as a separate discipline in the Enlightenment saw an attempt to establish this subject matter as a discipline of natural sciences. Functionalism, structuralism and structural-functionalism were some of the earlier rigorous theoretical frameworks for the scientific classification of anthropology. In the latter half of the nineteenth century, interpretives and postmodernists fervently opposed earlier claims that anthropology should be made a science, and critically raised questions of truth and objectivity in science. These theorists argued that anthropology is not an objective science; rather, they considered ethnographic data "text" that should be subjectively read, explained and interpreted. Questions of whether anthropology should be considered science or art, whether it is interpretive and discursive (as argued by the postmodernists) and whether it is a matter of universal law-making theory or more of a hermeneutic and humanistic discourse, are still very alive in and fundamental to anthropological literature. This article confronts these questions, examining the trajectory of anthropology from its classical to contemporary context.
\end{abstract}

Keywords: anthropology, anthropological theories, positivist vs. postmodern ethnography, interpretive and discursive anthropology

\section{Introduction}

The debate over whether anthropology should be considered a discipline of science, art, or anything else, is as old as the field of anthropology itself. Although the issue seems dated and gallons of ink have already been put into this matter, I add a few drops to consider its contemporary significance. Many founding anthropologists were inclined to label anthropology a scientific discipline, whereas others, in more recent times, have simply argued that the discipline of anthropology is more similar to humanistic or literary criticism. The latter group, led predominantly by Max Weber, Clifford Geertz, Michelle Foucault and James Clifford, argued that anthropologists produce new genres, and the ethnography they write closely matches with fiction and Verstehen. Anthropologists produce a reconstruction of their own habitus, influenced by their acquired schemata, emotional responses, dispositions and tastes. Such ethnography may not qualify as the product of natural-scientific knowledge. By revisiting the trajectory of anthropology from its classical to contemporary period, this paper examines whether anthropology can be considered a discipline similar to science, art or anything else. Before entering into this debate, it is necessary to revisit the basic nature and characterization of science to better examine the nature of anthropology against scientific facts and values.

\section{What Is Science?}

According to Webster's New World Dictionary of the American Language, science is defined as "Systematized knowledge derived from observation, study, and experimentation carried on in order to determine the nature or principles of what is being studied". In this definition, three factors are identified as essential characteristics of scientific exploration: (a) observation; (b) study; and (c) experimentation. Such a definition of science is very broad and inclusive, and, to be more precise, it can be said that science is the process of searching for fundamental and universal principles that govern the causes and effects of universal phenomena.

One fundamental requirement of scientific research is that the evidences used to claim and validate facts are empirical, so that ideas generated from research can be defended. Here, the empirical requirement refers to the 
background information used to support a theory, which must come from hands-on experience and be inspected and evaluated by other observers. Only evidences that meet such criteria can be considered scientific fact (Lavenda \& Schultz, 2000, 187). Scientific investigation has thus always stressed the importance of empirical research and hands-on collection of reliable information, which are preferred to speculative information unsupported by direct observation. A second important characteristic of scientific theory is falsifiability; if one cannot prove a theory wrong, it cannot be a scientific theory. For example, a theory that claims that there is life in the universe beyond Earth may be true, but it is not considered scientific fact because there is no such way to prove its falseness. Scientific theory is thus a "formal description of some part of the world that explains how, in terms of cause and effect, that part of the world works" (Lavenda \& Schultz, 2000, 187). From the above discussion, the following basic features of a natural-scientific fact can be derived:
a) Science is a process
b) Science must be empirical
c) Scientific claims must be defendable
d) Scientific facts must be observable and experimented by others
e) Scientific theories must be able to establish universal law

\section{Anthropology in the Nineteenth Century}

Early nineteenth century anthropological theories were mainly dominated by unilineal cultural evolutionism, and classical anthropologists such as Morgan, Tylor, Boas and Malinowski tried to establish anthropology as a branch of natural science. Through the theoretical perspective of unilineal cultural evolution, these classical anthropologists tried to explain the development of society in a unilinear way: from primitive through modern to complex societies. It was Morgan, the founder of British social anthropology, who emphasized that the variation of kinship pattern terminologies in different human societies across cultures correlates with patterns of family organization and subsistence. He assumed that all world cultures evolve through the same stages and sequences: from savagery through barbarism to civilization (Levanda \& Schultz, 2000, 188). Later on, Tylor, the founder of American cultural anthropology, observed the same unilineal cultural evolution, but denied the idea of diffusion. Tylor brought back the notion of the "psychic unity of mankind," originally proposed by Adolf Bastian and Franz Boas, to refer to the idea that mankind, under similar environmental conditions, will progress similarly in different parts of the world. Taking the evolution of religion as an example, Tylor explained that religion progresses in a unilineal way, from animism through polytheism to monotheism. Franz Boas and his students, on the other hand, argued against extreme evolutionary and diffusionist schemes. Boas rejected the idea of armchair anthropology and expressed the need for empirical fieldwork. Emphasizing the necessity of ethnographic information and historical evidence, Boas argued that there is no way to believe that culture changes over time through unilineal sequences; instead, cultures may sometimes be simplified rather than complicated. Boas used the notion of "historical particularism" to refer to the detailed historical and ethnographic data of any society and culture under study. Thus, Boas is considered one of the founders of ethnographic study, who believed in collecting data through fieldwork to establish scientific fact. Boas's anthropology is believed to be idiographic, as opposed to nomothetic.

Bronislaw Malinowski, one of the founder ethnographic fieldworkers, also tried to establish anthropology as science, using the concept of "functionalism" that he illustrated in his books A Scientific Theory of Culture and Other Essays (1944) and Dynamics of Culture Change (1945). Malinowski argued that one can understand the function of any cultural practice by asking three questions: Does it work? How does it work? and Why does it work? With these questions in mind, Malinowski founded the school of functionalism to establish the fact that every institution and custom has a social function. Malinowski argued that it is because of their function in society that religion, magic and all other institutions and practices exist. He explained that there are seven basic human needs: nutrition, reproduction, comfort, safety, relaxation, movement and growth, and culture is the instrument through which one can meet those needs. Thus, culture simply exists to meet the basic biological, social and psychological needs of the individual.

Malinowski's call for scientific and objective ethnographic writing is worth mentioning here. He pointed out that the researcher's responsibility is "to grasp the native's points of view, his relation to life and to realize his vision of his world," and emphasized that, without understanding the native's worldview and culture, it is impossible to write objective and scientific ethnography. A deeper understanding of local culture, language, social systems and values enables researchers to write an objective ethnography. Malinowski was heavily criticized by other anthropologists in the 1950s. One major criticism related to the question of whether it is possible for researchers 
to maintain objectivity, as many critics of Malinowski argued that it is impossible for researchers to understand a native's point of view (Geertz, 1973; Clifford, 1988; Clifford \& Marcus, 1986). Far from its objective standing, contemporary ethnographic writing has been understood as a matter of poetics and politics, guided by subjective understanding and interpretation (Clifford \& Marcus, 1986). A further criticism of Malinowski's project of functionalism has been that society maintains certain elements that are counterproductive to individuals, as well as nonfunctioning cultural materials. Despite all these criticisms, Malinowski is still appreciated for his contribution to ethnographic fieldwork and his efforts to establish anthropology as a scientific study.

Influenced by Durkheim, Radcliffe-Brown is also an important figure in British social anthropology. Radcliffe-Brown vehemently criticized the idea of functionalism as a "myth invented by Prof. Malinowski." Instead, he emphasized the study of the structure of society, which he proposed through the theory of structural-functionalism. Radcliffe-Brown explained function as "a condition in which all parts of the social system work together with a sufficient degree of harmony or internal consistency, i.e., without producing persistent conflicts which can neither be resolved nor regulated" (Radcliffe-Brown, 1952, 181). Malinowski's functionalism primarily stressed basic human needs at the individual level, whereas Brown's structural-functionalism focused more on societal need. Following Boas, Radcliffe-Brown refused the concept of culture; rather, he saw culture as a social system that can be studied scientifically, writing: "You cannot have a science of culture. You can study culture only as a characteristic of a social system. Therefore, if you are going to have a science, it must be a science of social systems" (Radcliffe-Brown, 1957, 106). Thus, Radcliffe-Brown, through his proposition of social structure, tried to establish anthropology as the science of social systems.

Thus far we have seen the emergence of British social anthropology in the hands of Durkheim, Malinowski and Radcliffe-Brown. In the mid twentieth century, we see an antagonism in perspectives between British social and American cultural anthropology. British anthropologists considered society the core subject matter of anthropology, whereas American anthropologists argued that culture, beliefs, values and ideas of human beings, which shape all aspects of human behavior and lifestyle, should be the central elements of anthropology. In reaction to the idea of social determinism, American anthropologists proposed the concept of cultural determinism. Kroeber (1917) argued that culture is a super organic phenomenon that, despite being created and carried out by individuals, transcends individuals. Pushing culture against Durkheim's notion of society, Kroeber mentioned that individuals can transcend into four different levels: body, psyche, culture and society. Ruth Benedict was a second influential figure to focus on the idea of culture and its influence on human beings. In her bestselling book, Patterns of Culture (1934), she characterized the Pueblo Indians as "placid and harmonious," Dobu Islanders as paranoiac and mean-spirited and Zuni Pueblo as Apollonian. Through such characterizations of different cultural groups, Benedict intended to demonstrate the manner in which culture shapes human behavior and constructs particular forms of social structure. By observing various cultural groups and practices, Benedict argued that there are infinite variations in world cultures and, thus, it is impossible to establish scientific explanation of cultural practice.

Ruth Benedict and Margaret Mead's attempt to psychoanalyze culture was a turning point in the history of anthropology, as it influenced the psychodynamics of culture that led such anthropologists as Benedict, Mead and Kardiner to establish the school of culture and personality. The main aim of this school of thought was to combine both anthropology and psychoanalysis to create a science of culture, which could help explain why adults from different cultures hold different values and personalities and engage in different cultural practices. It was argued that childrearing practices account for differences in personality between cultures (Lavenda \& Schultz, 2000, 192). Mead's first book, Coming of Age in Samoa (1928), tried to uncover whether rebellion, which marked adolescent personality in Western cultures, is a product of biological change occurring at puberty or a result of cultural influence. She concluded that adolescence in Samoa is not a sudden occurrence, but part of a gradual development of life, as human nature is not rigid and inflexible. Both Benedict and Mead tried to create a science of culture that could explain complex dynamics of human culture. However, two questions still remained: Is a human being a cultural robot? Is it possible to establish a science of culture based purely on childrearing practices?

Edward Evans-Pritchard emerged as an orthodox structural-functionalist whose anthropology was not a science, but more of a humanistic discipline. His most famous book, Witchcraft, Oracles and Magic among the Azande (1967), reveals how witchcraft and magic help maintain societal harmony and individual relationships. Evans-Pritchard proposed the theory of accountability to explain the ways in which witcheraft is used by the Azande to explain misfortune; as he explained, "I suppose that the simplest way of assessing an African people's way of looking at life is to ask to what they attribute misfortune, and for the Azande the answer is witchcraft" (Evans-Pritchard, 1967, 11). Thus, Evans-Pritchard's anthropology was humanistic, and he was more interested 
in understanding how socio-historical contexts shape the construction of ethnography. In writing about Evans-Pritchard's contribution to anthropology, Moore argued that "[c]entral to this was Evans-Pritchard's argument that anthropology should be modeled on social history rather than a science, and this call for a 'humanistic' anthropology resonates with many anthropologists today" (Moore, 1997, 158).

The discussion thus far has demonstrated that the origin of anthropology was guided by a more scientific orientation in the hands of functionalists, structuralists and structural-functionalists. Many classical anthropologists intended to study society in a scientific way. This makes sense if we look into the particular historical juncture between the fifteenth and seventeenth century (when scientific revolution took place), which provided the impetus for the discipline of anthropology to emerge and develop. Influenced by this backdrop of scientific revolution, many classical anthropologists wished to align anthropology with the discipline of natural sciences. In fact, many classical anthropologists were descendants of either biology or other disciplines in the natural sciences. Such an endeavor of scientific anthropology, however, began to fade in the nineteenth century, when many anthropologists questioned the field's scientific nature. These critical anthropologists raised questions of objectivity, scientific truth and other methodological inconsistencies that logically inhibited anthropology from scientific classification. The following discussion will show how anthropology took a rather humanistic, discursive and interpretive turn from the twentieth century onwards.

\section{Anthropology in the Early Twentieth Century}

Claude Lévi-Strauss is considered the most influential and ingenious anthropologist of the twentieth century. He founded French structuralism, which is rather different from Radcliffe-Brown's structuralism, as Lévi-Strauss's model transcends culture and society and enters into human mind and its underlying structures (Lévi-Strauss, 1958). Influenced by Saussure, Lévi-Strauss's structuralism is based on linguistics, which immediately gained international repute, particularly his structural studies of myth. Lévi-Strauss proposed that there are two aspects of the construction of myth: sequences of events, which form the apparent content of what happened, and myth schemata, which represent the different plans of abstraction on which the sequences are organized (Moore, 1997, 225). Similar to phonemes and morphemes in linguistics, there are "mythemes" and "kinemes" in mythology and kinship. Lévi-Strauss argued that, as all humans are of the same species, they possess the same innate mental structure and tendency to classify things in terms of binary oppositions such as male-female, day-night, mind-body, etc. Taking the myth of Oedipus as an example, he argued that mythemes must be studied at a sentence level, and, by breaking down a story into the shortest possible sentences, one can uncover particular subjects, meaning, functions and relations. By combining these structures, one is able to produce a meaning (Upadhyay \& Pandey, 1993, 296). Thus, Lévi-Strauss's structuralism is guided by the fact that the underlying patterns of thought are similar in all forms of human action and, therefore, the "savage" mind and the "civilized" mind have a similar innate structure and thinking (Lévi-Strauss, 1958).

In the mid twentieth century we see the return of cultural evolution in anthropology, but with different forms, explanations and scientific sophistications. Leslie White, like Malinowski and Radcliffe-Brown, intended to establish anthropology as science, and advocated for a general science of culture, which he proposed as "culturology." White's theory of cultural evolution is divided into three separate, but interrelated, subsystems: technological, sociological and ideological. White argued that all cultural evolution can be understood through the formulation of $\mathrm{E}^{*} \mathrm{~T}=\mathrm{C}$, where $\mathrm{E}$ stands for energy harnessed, $\mathrm{T}$ for time and $\mathrm{C}$ for cultural enhancement (White, 1949). With this formulation, White argued that cultural development is subject to energy harnessed and time efficiency of tools; he wrote, "[o]ther factors remaining constant, culture evolves as the amount of energy harnessed per capita per year is increased, or as the efficiency of the instrumental means of putting the energy to work is increased" (White, 1949, 368). Thus, White believed that cultural evolution is fundamentally determined by the use of technology, and the standard of technological sophistication sets two societies apart on a scale of cultural advancement. White further argued that humans' ability to create and use symbols sets them apart from other animals and enables them to carry out culture.

\section{Anthropology in the Late Twentieth Century}

In the latter half of the twentieth century, Marvin Harris emerged as an influential figure in anthropology. In reaction to cultural relativism and idealism, Harris proposed the theory of cultural materialism to focus on the material base of culture. Criticizing the idealistic and relativistic proposition that comparison between cultures is problematic because each culture is unique, Harris argued that these approaches discount the material base of a culture and put more emphasis on human minds (Harris, 1979). While distinguishing between emic (participant's point of view) and etic (observer's point of view), Harris argued that, by relying more on emic perspectives, anthropologists fail to gain a holistic understanding of phenomena. He believed that not all information provided 
by informants is easily understandable, and to have a science, one must have some etic perspectives, which cultural materialism may provide. In his book, Cannibals and Kings (1977), Harris argued that practices that may appear disgusting and shocking today - such as female infanticide, warfare and cannibalism - were all required for human survival and cultural evolution. Through cultural evolution, Harris argued, humans entered from freedom to slavery; the rise of the state, in particular, enslaved the human being.

In the 1960s, a different but extremely influential stream of anthropology emerged - mostly in the hands of Victor Turner and Clifford Geertz - which is often referred to as symbolic and interpretive anthropology. The main proposition of this stream is that emphasis should be given to systems of meaning and interpretation. Dissatisfied with the abstract nature of social structure, Victor Turner, while trained as a structural functionalist, began to emphasize that humans' unconscious conformity to the underlying principles of social structure help maintain societal order, practice and performance (Levanda \& Schultz, 2000, 196). Turner was even more interested in the use of symbols and, in particular, their use in expressing, shaping and resolving social conflict. Using the concept of "social drama," Turner argued that it is possible to explore the structure of a given society and the ways in which people's understanding of their society shapes their everyday lives. The concept of social drama, as proposed by Turner, consists of three stages: breach, crisis and redressive action, and integration through cultural symbols (Turner, 1988). Turner was not just satisfied with abstract cultural symbols; rather, he was particularly interested in exploring what people mean by a specific symbol and how such perception of a particular symbol leads to action in specific social situations. He used the concept of "communitas" to refer to a specific situation or rare incidence in social life when people forget their social structure and identity and act beyond the structure (i.e. transitional states experienced during out-of-the-ordinary situations such as rites de passage or pilgrimages) (Turner, 1969, 97).

Clifford Geertz is one of the most influential contemporary anthropologists, who prefers that anthropology be an interpretive discipline; as he argues: "The concept of culture I espouse, and whose utility the essays below attempt to demonstrate, is essentially a semiotic one. Believing, with Max Weber, that man is an animal suspended in webs of significance he himself has spun, I take culture to be those webs, and the analysis of it to be therefore not an experimental science in search of law but an interpretive one in search of meaning" (Geertz, 1973, 5). Thus, according to Geertz, there is no science of culture but only interpretation in search of meaning. He argues that culture is a system of meanings and symbols that are public and not private. By standing against Malinowski and cultural relativism, Geertz argues that it is impossible to gain the native's point of view; rather he prefers to see culture as a series of texts - stories that people tell themselves about themselves - and believes it is the anthropologists' responsibility to read these texts - not in the ways that natives would read them, but through collecting, analyzing and interpreting data. He proposes the concept "thick description" to refer to a type of ethnographic description that unveils latent meanings and explanations of cultural practices. He further argues that ethnographic description that emanates from intensive fieldwork should be interpretive, microscopic and discursive (Geertz, 1983). Such a Geertzian perspective on anthropology is often criticized for focusing more on subjective, interpretive skills, which make anthropology more like literary criticism than social sciences (Moore, 1997, 197).

At this point of interpretive anthropology, the issue that really draws anthropologists' attention is the distinction between "facts" and "values." By "facts," anthropologists generally refer to the everyday realities that subjects encounter; "values," in contrast, refer to evaluative criteria through which subjects make sense, perceive or assess those realities. Contemporary anthropologists are encouraged to carefully discern facts and values. If they fail to do so, their understanding and representation of reality will be incomplete, biased or judgmental. It has been argued that laypeople tend to explain reality without critical, in-depth or latent exploration. Here lies the difference between anthropological and lay explanation. For anthropologists, the explanation or evaluation of reality must be value free, objective and critical. Explanation of a fact or reality cannot be considered a form of knowledge unless it is objective and explores the latency of the fact (Sperber, 1985).

This leads to a very crucial and contested question in anthropology: Can anthropological representation really be value-free (or, can anyone be truly objective and detach themselves from their subjective experience)? Anthropologists are now at crossroads on this issue. Many anthropologists consider social reality an illusion because of "taking our social arrangements for granted because we know of no others; ideological distortions based on the interests and perspectives of our social positions; inability to detach ourselves from an evaluative stance; repression of things that make us feel shameful and guilty" (Collins \& Makowsky, 1993, 8). In many ways, anthropology has lost its virginity in relation to being neutral, objective and value-free. Many contemporary anthropologists passionately stand beside the exploited racial minorities in America and oppressed peasants in the third world, standing in favor of morality and humanity. Critical anthropologists now engage with 
contemporary politics and its flaws. They fight for minimizing the plight of the oppressed and take stands to rationalize military support for uprooting dictatorship in Chile, Africa, Iraq, Central America and elsewhere (Rubinstein, Fosher \& Fujimura, 2012; Lucas, 2009).

The emergence of postmodern anthropology in the twentieth century profoundly criticizes scientific authority and objectivity and argues that the world around us cannot be objectively described, since everything appears as a matter of conflicting interpretation or merely "incredulity towards metanarratives." The central argument of postmodern anthropology is that the universalizing and reductionist claim of positivists are inapplicable, irrational and inadequate for understanding contemporary, diverse cultural practices. Postmodern anthropologists approve a standpoint that takes symbolic culture seriously, and argue for a "reflexive, interpretive approach in which the details of specific cultural realities are not eliminated, in which people's individual voices and their unique understandings are not silenced by generalizations" (Lavenda \& Schultz, 2000, 201). Postmodern anthropology questions the nature of truth when, today, image is everything. The writing of James Clifford and George Marcus (1986) delineates why anthropologists cannot objectively describe the cultural world they study. These authors argued that anthropologists write texts and literary genres that are heavily influenced by audience expectations and institutional and global power structures. Anthropologists have no privileged access to cultural truth; rather, they write from their own subjective positions, which are inevitably influenced by power relations and politics, within which research is an integral part.

Since the 1950s, cultural studies have stood as a reaction against "scientific" social science. Many scholars, such as Derrida, Gramsci, Foucault and Baudrillard have approved the Geertzian proposition of anthropology that emphasizes the significance of subjectivity, power structure and political relations in the observation and interpretation of cultural facts. They have disapproved of the pursuit of static and impossible "objective truth," and further questioned the pursuit of scientific anthropology with the argument that ethnographic findings are contextual and subject to individual observation and interpretation, which may not be representative outside the context of research. Thus, it has been rightly argued that "whatever anthropology is, it is not a science, and the knowledge anthropologists create is in no sense scientific. Anthropological knowledge is interpretive and hermeneutic rather than positive, tentative rather than conclusive, relative to time, place and author rather than universal" (Carrithers, Whittaker, Rubinstein, Roth \& Keesing, 1990, 263).

\section{Conclusion}

It has been quite evident in the above discussion that anthropologists are divided into two blocs on the issue of whether anthropology should be a subject of science, art or anything else. The founding anthropologists, identified as positivists, upheld the traditional sense of science and argued that universal and objective truth can be established by rational methods and procedures that ultimately unify the knowledge of all domains under one grand "theory of everything" (Lavenda \& Schultz, 2000, 201). This standpoint of anthropology as science is historically appropriate, given the natural science background of the founding anthropologists and the influence of the Enlightenment and scientific renaissance from the fifteenth century onwards. On the other end of the bloc, mostly contemporary anthropologists such as Evans-Pritchard, Lévi-Strauss, Turner, Geertz, Clifford, Marcus and Foucault have strongly opposed earlier claims of scientific anthropology. By illustrating the impossibility of objectivity and scientific validity, they have proposed a humanistic and hermeneutic anthropology grounded in subjectivity, interpretation and discursive analysis. From the postmodernist point of view, anthropology cannot be a science because there is no universal human behavior and culture. Thus, truth and objectivity are subject to specific sociocultural, historical and political contexts. Postmodern anthropology considers society as "moral systems and not as natural systems ... it is interested in design rather than in process, and ... it therefore seeks patterns and not scientific laws, and interprets rather than explains" (Evans-Pritchard, 1962, 26).

Thus, in addressing the question of whether anthropology should be classified as a natural science, we observe two extreme lines of thought: extremes of determinism and extremes of relativism. Claims made by anthropologists in earlier periods have become problematic in contemporary contexts. Although Malinowski's urge to search for the "native's point of view" is still quite influential in contemporary anthropology, postmodern anthropologists' argument on the impossibility of accessing natives' thinking patterns also make sense. Therefore, it is problematic to stand on either of these extreme ends; rather, anthropologists would be safe to take a position between these two extremes. There is no denying that anthropology has come a long way from its origin. Along the way, in incorporating changing contexts and dynamic sociocultural situations, anthropologists have offered various theoretical propositions. It may be concluded that anthropology is a blending prefecture of science, art and literary criticism that is both scientific and hermeneutic in nature. The postmodern ethnography would be, as Sperber (1985) argued, "the resulting description is actually what the ethnographer selected from what he understood of what his informants told him of what they understood" (Sperber, 1985: 15). 


\section{References}

Benedict, R. (1934). Patterns of culture. Boston: Houghton Mifflin.

Bohannan, P., \& Glazer, M. (1988). High points in anthropology. New York: Alfred A Knopf.

Brown, R. (1965). Structure and function in primitive society. New York: The Free Press.

Carrithers, M., Whittaker, E., Rubinstein, R. A., Roth, P. A., \& Keesing, R. M. (1990). Is anthropology art or science? Current anthropology, 31(3), 263-282. http://dx.doi.org/10.1086/203840

Clifford, J. (1988). The predicament of culture: Twentieth-century ethnography, literature, and art. Cambridge: Harvard University Press.

Clifford, J., \& Marcus, G. (1986). Writing culture: The poetics and politics of ethnography. Berkeley: University of California Press.

Collins, R., \& Makowsky, M. (1993). Society and illusion. In R. Collins \& M. Makowsky (Eds.), The discovery of society, 1-16. New York: McGraw Hill.

During, S. (1993). The cultural studies reader. London: Routledge. http://dx.doi.org/10.4324/9780203190784

Erickson, P. A., \& Murphy, L. D. (2001). Readings for a history of anthropological Theory. Peterborough CA: Broadview.

Evans-Pritchard, E. E. (1962). Essays in social anthropology. London: Faber.

Evans-Pritchard, E. E. (1967). Witchcraft, oracles and magic among the Azande. Oxford: Oxford University Press.

Geertz, C. (1973). The interpretation of cultures. New York: Basic Books.

Geertz, C. (1983). Local knowledge: Further essays in interpretive anthropology. New York: Basic Books.

Harris, M. (1977). Cannibals and kings: The origins of culture. New York: Random House.

Harris, M. (1979). Cultural materialism: The struggle for a science of culture. New York: Random House.

Kroeber, A. L. (1917). The superorganic. American anthropologists, 19(2), 163-214. http://dx.doi.org/10.1525/aa.1917.19.2.02a00010

Langness, L. (1987). The study of culture. Novato, CA: Chandler \& Sharp.

Lavenda, R. H., \& Schultz, E. A. (2000). Core concepts in cultural anthropology. Mountain View CA: Mayfield.

Lévi-Strauss, C. (1958). Structural anthropology. New York: Basic Books.

Lucas, G. R. (2009). Anthropologists in arms: The ethics of military anthropology. Lanham: AltaMira Press.

Malinowski, B. (1944). A scientific theory of culture and other Essays. Chapel Hill: University of North Carolina Press.

Malinowski, B. (1945). The dynamics of culture change: An inquiry into race relations in Africa. New Haven: Yale University Press.

Moore, J. D. (1997). Visions of culture: An introduction to anthropological theories and theorists. Walnut Creek, CA: Altamira Press.

Radcliffe-Brown, A. R. (1952). Structure and function in primitive society: Essays and addresses. Illinois: The Free Press.

Radcliffe-Brown, A. R. (1957). A natural science of society. Glencoe, Illinois: The Free Press.

Ronald, B. (1972). Mythologies. New York: Hill and Wang.

Rubinstein, R. A., Fosher, K., \& Fujimura, C. (2012). Practicing military anthropology: Beyond expectations and traditional boundaries. Boulder: Kumarian Press.

Sperber, D. (1985). On anthropological knowledge: Three essays. Cambridge: Cambridge University Press.

Turner, V. (1969). The ritual process: Structure and anti-structure. New York: Aldine De Gruyter.

Turner, V. (1988). The anthropology of performance. New York: PAJ Publications.

Upadhyay, V. S., \& Pandey, G. (1993). History of anthropological thought. Concept: New Delhi.

White, L. A. (1948). The science of culture: A study of man and civilization. New York: Grove Press.

\section{Copyrights}

Copyright for this article is retained by the author(s), with first publication rights granted to the journal.

This is an open-access article distributed under the terms and conditions of the Creative Commons Attribution license (http://creativecommons.org/licenses/by/3.0/). 